\title{
Assessing the Significance of Auditing Small Businesses and Organisations; a Case Study of Selected Organisations in Ghana
}

\author{
Dickson Akoto \\ Radford Business School, Radford University College, Accra, Ghana \\ Email address: \\ dickakoto2003@yahoo.com
}

To cite this article:

Dickson Akoto. Assessing the Significance of Auditing Small Businesses and Organisations; a Case Study of Selected Organisations in Ghana. International Journal of Accounting, Finance and Risk Management. Vol. 6, No. 2, 2021, pp. 46-52.

doi: 10.11648/j.jjafrm.20210602.12

Received: January 27, 2021; Accepted: March 26, 2021; Published: April 20, 2021

\begin{abstract}
Auditing is a necessary tool for business management; however, many small businesses and organisations ignore it. The lack of audits has caused the collapse of many of these businesses since probity and accountability are essential for the growth of businesses. The researcher, observes that small businesses lack the capacity to employ auditors, citing cost of audit fees as the reason. This invariably makes them more prone to fraud hence the collapse of their businesses. He therefore, resolved to analyse the effect that auditing small business have had on some organisations that he had personally audited over the years and make relevant recommendations to businesses. The research shows that small business are even more vulnerable because of lack of qualified accounting personnel in managing their books of accounts hence the need to employ auditors to evaluate the organisations activities. The research also shows that the presence of an auditor alone is a moral deterrent to fraudsters. The researcher recommends that small businesses should be educated on the importance of audits by stakeholders including finance professionals. Auditors should consider charging small businesses reasonably low audit fees to encourage them have their accounts audited. As observed in the case study, when the small businesses are audited they will begin to operate efficiently and the auditor will be able to charge economical fees as the businesses grow.
\end{abstract}

Keywords: Auditing, International Financial Reporting Standards, Auditing Standards

\section{Introduction}

Many small businesses do not implore standard accounting principles in their businesses because they claim they do not have the funds to employ skilled accounting personnel to take charge of their books of account and prepare their financial statements. In the same vein, many do not see the need to employ the services of auditors to review their accounts and report thereon; they as well assign financial difficulties as their reason.

The current International Financial reporting Standards (IFRS) and auditing standards that require that volumes of reports be written when preparing the published accounts of businesses and reporting thereon have made many small businesses more reluctant to employ the services of qualified accountants since they perceive that the cost to them will even be higher. Although, the standards have reduced the extent to which small businesses accounts be reported on, many small businesses still are not ready to allow their businesses to be audited, especially in Ghana where businesses are rarely penalized for not publishing their accounts. Managers of many of such small businesses, therefore, commit fraud and go undetected by their owners and members in the case of organisations.

This situation has prompted the researcher to establish the significance of auditing such small businesses and organisations since they are more prone to material misstatements and fraud owing to the fact that many of them do not have skilled personnel managing their accounts. He has chosen a few small organisations that he has personally appraised their performances and expounded the misrepresentations that were found in those organisations that would have gone undetected if their accounts were not scrutinised. He also brings to the fore benefits that inure to 
those organisations as a result of the audits conducted on their operations.

Auditing is a necessity and every institution should subject itself to audits if it wants to grow. In financial management, it is asserted that although the primary objective of a private enterprise is profit maximisation, there is the postulate that when the enterprise in not managed by the owners but rather managers, profit maximisation, therefore, ceases to become the primary objective of the enterprise. This is because it is suggested that managers will put their interest ahead of the interest of the owners and will not be keen to maximise profits.

This phenomenon has led to conflict between managers and shareholders over the years, ACCA Financial Strategy [1]. Among the solutions to this conflict, therefore, is to have the accounts of the businesses audited annually for the shareholders to be satisfied that their assets have been safeguarded; and to have the chance to query the mangers if there is evidence of inefficient use of the businesses' resources. The managers will also be satisfied that when the accounts are audited suspicions about their operations will be put to rest; and shareholders will have confidence in them. This assertion is confirmed by Glover and Prawitt [2] who state that reporting to an agreed-upon set of accounting principles does not solve the problem by itself. Because the manager is responsible for reporting on the results of his or her own actions, which the absentee owner cannot directly observe, the manager is in a position to manipulate the reports, therefore, the need for an auditor.

\section{Literature Review}

Auditing can be defined as the examination by an independent person of the books of accounts and the financial statement of an organisation to ascertain if the accounts represent true and fair view of the state of affairs of the organisation. In doing this, the auditor determines if the laid down principles and regulations have been complied with and if the internal control is strong enough to produce an accurate result. Auditing should be financial and otherwise, for example management audit, staff audit, etc. Auditor's job is to safeguard the asset of the company. The auditor checks if the organization is operating in a manner that it has been set up to do, and if it is operating effectively, efficiently and economically in order to produce the desired results and remain a viable entity.

According to Siddiqui [3] auditing is a formal examination of accounting books, documents and vouchers of a business concern in order to verify the profit and loss and the financial position of a business. It's a systematic check or assessment of financial records of a business, department or organization to establish accuracy or efficiency or effectiveness

According to Millichamp [4] the objectives of auditing are twofold; the primary and the subsidiary objectives: Primary objective - to produce a report by the auditors to the truth and fairness of the financial statement so that any person reading and using them can have belief in them. Subsidiary objective is to detect errors and fraud; to detect errors and fraud by deterrent and moral effect of the audit; to provide spin-off effects. The auditor will be able to assist his client with accounting systems, taxation, financial and other problems.

The primary objective of audits, as stated above is to produce a report by the auditors to the truth and fairness of its financial statement. This is essential for the myriad of users of the financial statements. Included in the users of the financial statements are owners or shareholders; Lenders, Employees, Customers, Suppliers, Accountants, stock brokers, Trade Unions, Government/ tax authorities, The public, political and other pressure group and investors. A company that gets its accounts audited stands the chance of wooing investors and other stakeholders to its business, thereby expanding its operations.

The deterrent and moral effect of an audit is another powerful aspect of audits. The very fact that the organisation employs the services of an auditor whether internal or external puts some level of fear in persons who desire to commit fraud in the business. They become mindful of the fact that one day their deeds may be uncovered, therefore; they either postpone the committal of crime or abrogate the idea entirely. When an auditor enters the client's premises, potential fraudster in the organisation become alarmed and at times their very demeanour gives them up to the auditor to investigate their roles in the organisation. This enables the auditor detect fraud and safeguards the assets of the organisation. The importance of an audit, therefore, cannot be overemphasized. This is most important for small businesses and organisations where segregation of duties is minimal, internal controls are weak and the directors have little or no financial knowledge in running their businesses. The work of an auditor helps to forestall these anomalies and move the business to the next level.

\subsection{Internal Auditing and Control}

According to Hohler A. [5] internal control is classified mainly into control environment and control procedures or activities, statement of Auditing standard (SAS, 30). Recchiuti [6] asserts that the policies and procedures designed for information systems for management is established to provide reasonable assurance engagement aimed at attaining the objective of control environment. Lamoye [7] also indicates that for the control system to be effective and efficient, there should be relevant and reliable information which should be recorded and communicated to management and other personnel within the organization

\subsection{Internal Audit}

Obazee [8] defines internal audit as an independent activity objectively determined to add value and improve the organization's operations and by helping them to achieve their objectives through a systematic and disciplined method to evaluate and improve the effectiveness of risk management and control processes and governance. 
Scheduling audits on a calendar helps ensure they are performed consistently. Departments should be given notice so they can have the required documentation and materials available for the auditor. A surprise audit may be conducted if suspicion of unethical or illegal activity exists.

According to Cohen and Sayag [9], internal audit activities are critical part of the success of an organisation and according to Ljubisavljevic and Jovanovi [10] internal audit makes a large contribution to the achievement of company goals and the implementation of strategies for their achievement.

According to Lander [11], internal control is for financial reporting as a process by or under the supervision of the company's principal executive and principal officers and implemented by company's board of directors, management and other personnel to provide reasonable assurance for the reliability of financial reporting and the preparation of financial statement of external purposes in accordance with generally accepted accounting principle. According to Hayes et al [12], however, internal controls offer fair but not outright assurance to a business management that the organisation's objectives will be achieved. Sarens and De Beelde [13] also assert that a sound system of internal control provides reasonable but not absolute assurance that a company will not be hindered from achieving its business objectives by circumstances which may reasonably be foreseen.

According to Khan [14], internal control systems are classified as below:

\subsubsection{Preventive Controls}

Preventive controls are designed to keep errors or irregularities from occurring in the first place. They are built in to internal control systems and require a major effect in the initial design and implementation stages. However, preventive controls do not require significant on-going investments.

\subsubsection{Detective Controls}

Detective controls are designed to detect errors and irregularities, which have already occurred and to assure their prompt correction.

\subsubsection{Corrective Controls}

Corrective controls are designed to correct errors or irregularities that have been detected.

\subsection{Internal Audit Procedure}

An internal audit begins by an auditor assessing current processes and procedures. The auditor then analyzes and compares the results to internal control objectives. He determines whether the results comply with internal policies and procedures as well as state and federal laws. Finally, the auditor compiles and presents an audit report to the business owner.

\subsection{Assessment Techniques}

Assessment techniques ensure an internal auditor completely understands internal control procedures and determines whether employees comply with internal control directives. An auditor avoids disrupting the daily workflow by beginning with indirect assessment techniques. For example, he may review flowcharts, manuals, departmental control policies or other existing documentation, or he may trace specific audit trails from start to finish. Substantive procedures such as transaction matching, physical inventory count, audit trail calculations and calculating alreadyreconciled financial statements help determine whether work products contain data entry errors or whether financial statements contain misstatements.

\subsection{Reporting Procedures}

Internal audit reporting always includes a formal report and may include a preliminary or memo-style interim report. An interim report typically includes sensitive or significant results the auditor feels are pertinent for immediate sharing with the business owner. The final report is more formal than the interim report.

\subsection{Audit Evidence}

Audit evidence is the information collected for review of a company's financial transactions, internal control practices and other factors to enable an auditor form an opinion on the accounts being audited. According to ACCA Audit and Assurance [15], the objective of the auditor, in terms of gathering evidence, is described in ISA 500 Audit Evidence as to design and perform audit procedures in such a way to enable the auditor to obtain sufficient appropriate audit evidence to be able to draw reasonable conclusions on which to base the auditor's opinion. Sufficiency relates to the quantity of evidence, appropriateness relates to the quality or relevance and reliability of evidence

\subsection{External Auditing}

An external audit, is defined as a company audit which is performed by a party which is not employed by the business to be audited. This audit can be done annually or biannually depending on the terms of engagement. The external auditors report their findings to the shareholders of the company. Since the external audit is performed by persons outside the company, conflict of interest is less likely to occur than that in the case of internal audit.

\subsection{Differences Between Internal and External Audits}

Millichamp [16] differentiates internal and external audits in terms of; scope of the audits, approach and responsibility. He asserts that the internal auditor performs his duties as prescribed by management (his employers) whereas the external auditor perform his duties as per statutes. The approach of the internal auditor in the performance of his duty is to ensure accounting system is efficient and provide management with accurate and material information. The external auditor's approach however, is to satisfy himself that the financial statement to be presented to the shareholders 
represent a true and fair view. The internal auditor is responsible to the management (his employers) whereas the external auditor is responsible to the shareholders.

\subsection{Similarities between Internal and External Audits}

For both the internal and external auditors their primary determination is to ensure effective internal control system in the organization since this is vital for the sustenance of the organization and also for them to have confidence that the reports that they produce on their audits are authentic. An effective internal control system will ensure that the accounting information flow is sound and reliable. Finally, both types of auditors' duty is to safeguard the assets of the organization; be it cash, inventory, accounts receivable or non-currents assets of the entity.

Internal auditing is undertaken by businesses that have adequate resources to finance their operations. These are normally large or medium scale enterprises. External auditing is done by all classes of businesses. Where internal auditing exists, the entities' internal controls are strengthened since the internal auditors have daily oversight responsibility over the controls of the business. It helps to facilitate early detection of material misstatements and mitigate fraud in the businesses and makes the work of the external auditor easier. The length of time that the external auditor would spend on the audit would be lessened since the internal controls can be relied on as effective enough to warrant the use of risk-based audit strategy for the audit. This also makes the external auditor invariably charge lower fees for the audit; as the audit fee is proportional to the time spent on the audit.

The work of the internal auditor, therefore, compliments that of the external auditor. Practically, when an external auditor goes for an audit, he reaches out for the internal auditors report and file, peruses them and uses the information in the internal auditor's report to assist him in the conduct of his audit. Both internal and external auditors work are important for the small businesses and organisations; nonetheless, since small businesses may not have the resources to hire the services of both internal and external auditors, they normally go in for the external auditor who comes to audit at the year-end and is paid as such. As explained earlier in this work, the bane of the small businesses and organisations is that, they are sometimes reluctant to even hire the services of the external auditor. The resultant effect is that fraud is normally perpetrated and goes undetected and eventually leads to the collapse of their businesses.

\subsection{The Importance of Audits}

According to Siddiqui [3], the need of audit arises due to the fact that a business enterprise needs to ensure the correctness of all accounts pertaining to the business. It is also important to ascertain whether or not, the financial statements, profit and loss account and balance sheet have been prepared in a way as to show the summary of the flow of transactions for the whole period and the true picture and position of a business enterprise. Besides, in order to ensure the accuracy or the efficiency of the records, detection and prevention of errors is vitally important. Hence, audit, under its main objectives and subsidiary objectives fulfils the purpose.

Audit is an effective tool for Business Management, as internal audit is conducted in order to ensure the policies are being followed. It enables making valuable suggestions for improvement and to formulate future policies of a business. Audit also helps management to review the policies from time to time. Since audit involves a detailed verification of accounting records, it helps greatly to discover errors or frauds while it promotes a moral check on the employees through which their efficiency may also be determined. Audit can motivate the employee to maintain the efficiency leading to increase their performance level. With the help of audit, misappropriation of goods and manipulation of records may be identified.

Audit is of great importance to gain confidence in investors of a joint stock company. Since the audited statements are very much useful, the investors can ensure whether or not they need to invest capital, Siddiqui [3]. In addition, according to Van peursem [17] internal auditors are important, even crucial, in an economy that relies on independently produced information.

According to Bansal [18] benefits of legal and financial audits are as follows:

Better rate of securing financing

Preparation for business growth

Lower interest rates on business loans

Identifying business weaknesses to avoid future tax penalties

Howes [19] also asserts that among the reasons for auditing financial statements is to have a handle on one's finances.

An auditor is as well required to evaluate the client's business to give expert advice to the client. This function of the auditor is very vital for the sustenance of the client's business. A client who is not a finance expert may be operating unknowingly at a loss although the company may be making revenue. Eventually, the company may consume all its retained profits and start consuming part of its capital. The absence of an auditor for such an entity may be detrimental to its survival.

\section{Methodology}

The researcher has chosen four small not-for-profit organisations that he appraised in his line of duty as a member of an audit team that audited those organisations. The research design is qualitative.

\subsection{Data Collection}

Primary data was collected from four audited organisations for the conduct of the audits. These data were extracted from receipts, invoices; goods received notes, note books and cash analysis books. In organisations where financial statements 
were not available the researcher used these documents to prepare the financial statements; after which the accounts were audited.

\subsection{Data Analysis}

The researcher analysed the results obtained from the audit of these organisations in order to ascertain whether or not there is the need to audit small businesses and organisations.

For the sake of auditor-client confidentiality, the researcher did not disclose the actual names of these organisations but rather used the alphabets $\mathrm{A}, \mathrm{B}, \mathrm{C}$ and $\mathrm{D}$ to describe them. This is because most of these organisations displayed smacks of misrepresentations and fraud in their dealings. The disclosure of this to the public could have damning repercussions on them and the auditor-client relationship.

\section{Results and Findings}

\subsection{Organisation $A$}

The researcher as a member of an audit team conducted audit on a small scale not-for profit organisation in 1993 in Accra. The organisation was established in 1978; its accounts were never audited till 1993. Being the first audit of the organisation, several internal control weaknesses were identified. In addition to that, financial breaches were detected in the organisation via the first audit.

\section{Benefits Derived From the Audit}

Before the first audit, the organization in Accra had lived in a dilapidated structure for 15 years. Immediately after the audit, members had confidence in the system and became willing to provide funds immensely for the good of the organisation. As a result, within four years after the first audit the organisation built two-storey sandcrete permanent structure for its activities. A feat that could not be achieved in 15 years was done in four years owing to the audits that had been welcomed in the organisation. The building is now a great edifice in Accra. This shows that companies and organisations whose accounts are audited get access to funds. This research also shows that the company does not need to be large before accessing funds, if only its accounts are audited it stands the chance of obtaining funds for its operations. It also confirms the assertion of Siddiqui [3] that audit is of great importance to gain confidence in investors. Since the audited statements are very much useful, the investors can ensure whether or not they need to invest capital. In this instance, the investors are the members of the organization who decided to generate funds to the organization because its accounts had been audited and they now had confidence in it to invest more funds that they had generated.

\subsection{Organisation $B$}

The researcher was a member of a team that audited the accounts of a small scale organisation in Accra in 2000. This organisation had never been audited since its establishment five years earlier. A lay man's thought was that the more the audits delayed the better it was to conceal facts and misstatements However, this audit proved the novices wrong because if only good records are kept no matter the length of time, an audit would reveal misstatements and misappropriations, if any. In the course of this audit, an amount of GHC6,000 equivalent to $\$ 5,000$ was detected to be misappropriated, spanning over the five years of the organisation's establishment. The organisation's turnover for the year of the audit was GHc 20,000, that's \$16,666. The financial misstatement was therefore $30 \%$ of that year's turnover. The amount involved was therefore material. Another fraudulent transaction that escaped every ordinary person that saw the bank statements of the organisation was also detected by the researcher. A unique sum of money that was repeated every month on the bank statement caught the researcher's eyes; and he investigated those figures. Upon enquiry, the researcher realised that the operators of the organisation's account had arranged fraudulently to acquire an asset for an executive member of the organisation without the approval and knowledge of management.

\section{Benefits Derived From the Audit}

As in the case of the first organisation, the members of this organisation, now believing that their funds were safe under the eagle eyes of the auditors, began investing greatly in the organisation and great feats were achieved. Members of the organisation then became eager to hear the auditors' reports year after year and that spurred them on to ensure the safety of the organisation's funds. The management of the organisation also refrained from fraudulent activities knowing that audits would be conducted on the accounts. This confirms Milichamp [20] assertion that one of the objectives of auditing is to detect errors and fraud by the deterrent and moral effect of the audit.

\subsection{Organisation $C$}

In 2012, the researcher audited the accounts of a small organisation and during the audit he realised that there was a short fall in cash balance of $\mathrm{GHc} 8,000$ equivalent to $\$ 5,500$. The organisation's turnover for that year was GHc 21,000, which is $\$ 14,500$. The amount involved was $38 \%$ of the turnover. The amount involved was therefore, material. Being oblivious of the fact that such small organisation could indulge in such fraudulent deed; the researcher spent longer period reviewing his work trying to convince himself of the authenticity of his findings. Finally, when he approached the top hierarchy of the organisation of his findings, one of the executive members confessed that he had deposited the said amount in his personal account on behalf of the organisation. The researcher conducting the 2013 audit realised that the amount had been repaid in 2013 .

\subsubsection{Benefits Derived From the Audit}

The executives of that organisation realised it was not easy to commit fraud in an organisation without detection by the auditor.

At the end of the following year 2014, the organisation did not submit its account for audit with the reason that it wanted 
to submit two-year accounts (2014 and 2015) for audit. At the end of 2015 accounting period, the organisation submitted the two years account for audit. In the course of the audit, the researcher again observed that there was financial malfeasance by the organisation in the year 2014 to the tune of GHc 6,300, equivalent of $\$ 4,200$ which was cleverly repaid in 2015. The organisation's turnover for 2014 was GHc26, 000. The amount involved was therefore $24 \%$ of the turnover and was material. This showed that, the organisation knowing that it had misappropriated funds in 2014 declined to submit its accounts for 2014 for auditing with the view that when it puts the money back in 2015 it would not be detected.

\subsubsection{Benefits Derived From the Audit}

With this latest development, after the researcher pointed out the anomaly to the executives of the organisation, they finally got convinced that one of the benefits (secondary objective) of having an account audited is to have fraud detected; hence they ceased perpetuating fraud in the organisation.

\subsection{Organisation D}

In the year 2010, the researcher was granted the opportunity to audit a small not-for-profit organisation, specifically a basic school. The expectation of the client of course was detection of fraud in the school. The researcher began his work; just to realise that basic books were not kept. The records that spanned over three years had discrete information. Records were kept for certain periods and were ignored in other periods. Since full records were not available for the audit, the auditor could not even prepare the financial statements; therefore the organisation could not be audited.

\subsection{Inference}

The researcher observed that for every business to be audited effectively whether large or small there was the need for the business to keep basic records of its operations. This is inferred from the fact that during the researcher's audits of organisations A, B and C, although proper books of accounts were not kept, basic continuous records were available that enabled the organisations to be audited and reports produced. However, in the case of organisation D, it could not be audited because basic records of transactions were not available and those available were not a continuous flow of accounting information.

This emphasises the need for small businesses and organisations to keep at least basic records that provide accounting information to enable auditing to be performed. This confirms the literature of Siddiqui [3], that auditing is a formal examination of accounting books, documents and vouchers of a business concern in order to verify the profit and loss and the financial position of a business. This implies that when accounting books, documents and vouchers of the business are not available audits cannot be effectively conducted.

\section{Conclusion}

From the audits of the above four organisations, it was observed that small businesses and organisations, by their nature, have weak internal controls and prone to fraud. These fraudulent activities are material but go unnoticed for many years and the loss to the businesses may be far more than the cost of auditing them; hence there is the need for small businesses and organisations to be audited.

\section{Recommendations}

Businesses and organisations, no matter the size should be educated on the need to keep proper books of account; at least they should keep basic records, documents and vouchers that will enable accounts to be prepared. These records should be continuous flow of accounting information.

Stakeholders of small businesses and organisations should be advised that by the nature of their operations controls are bound to be weak, therefore, they must urge the managers of their businesses and organisations to prepare financial statements.

These stakeholders should ensure that the accounts of their businesses are audited annually.

Accountants and finance professionals should act as ambassadors of the profession anywhere they are present to sensitise the society on auditing no matter the size of the organisations; this will help businesses grow and create jobs for the accounting professionals as well.

Auditors should consider charging small businesses reasonably low audit fees to encourage them have their accounts audited. As in the cases above when the small businesses are audited they will begin to operate efficiently and the auditor will be able to charge economical fees as the businesses grow.

\section{References}

[1] ACCA, Financial Strategy (2000), BPP Publishers, UK.

[2] Glover, S. M, Prawitt D. F (2008) Auditing and Assurance Services, a systematic approach, fifth edition, Mcgraw-Hill, Irwin.

[3] Siddiqui F (2017). The importance of audits.

[4] Millichamp, A. H (2002), Auditing, book power, London.

[5] Hohler A. (2005) Control and Commend: Real Finance Journal, November pp43-49.

[6] Recchiuti W (2001), Control Activities-Deloitte.

[7] Lamoye (2005); internal control and cost; NF Perspective Journal pg 4.

[8] Obazee, H (2009) The corporate governance mosaic and financial reporting quality, Journal of Accounting Literature, vol. 23, pp 87-152.

[9] Cohen, A., and Sayag, G.(2010). The effectiveness of internal auditing: an empirical examination of its determinants in Israeli organisations. Australian Accounting review, 2093 0, 296-307. 
[10] Ljubisavljevic, S and Jovanovi, D (2011). Empirical research on the internal audit position of companies in Serbia. Economic Annals, LVI (191), 123-141.

[11] Lander G. P (2004). What is Sarbanes Oxley, MC Grew -Hill, New York Messier.

[12] Hayes, R Walage, P., Gortemaker, H (2014). Principles of auditing, an introduction to international standards on auditing Pearson Higher Ed.

[13] Sarens, G and De Beelde I (2006). The relationship between Internal Audit and Senior Management: A qualitative analysis of expectations and perceptions. International Journal of Auditing 10 (3); 219-241.
[14] Khan, K. (2006), How governance is changing, vol. 17, No 5, p. 21.

[15] ACCA, Audit and Assurance (2018), Kaplan Publishing, UK.

[16] Millichamp, A. H (2000) Auditing, $7^{\text {th }}$ edition Continuum

[17] Van peursem K. A (2005), managerial auditing journal vol 20 issue 5 pp 489-512.

[18] Bansal G (2017), Importance of Audit in an Organisation.

[19] Howes C (2017) 6 Reasons why you should Audit your Financial statements, 6/2/2017.

[20] Millichamp. A and Taylor, J (2008), Auditing pat Bond, London. 